\title{
PENGARUH CURRENT RATIO (CR), DEBT TO ASSET RATIO (DAR), PERPUTARAN PERSEDIAAN (INVENTORY TURNOVER), DAN UKURAN PERUSAHAAN TERHADAP PROFITABILITAS PADA PERUSAHAAN PROPERTY DAN REAL ESTATE DI BEI PERIODE 2012 - 2016
}

\author{
Silvia $^{1}$, Vinna Jovani ${ }^{2}$, Fransisca ${ }^{3}$, Catherine Grace ${ }^{4}$, Roby Gunawan $^{5}$, Hottua Samosir $^{6}$, \\ Jonris Tampubolon ${ }^{7}$ \\ 1,2,3,4,5,6,7 Prodi Akuntansi, Fakultas Ekonomi, Universitas Prima Indonesia, Jalan Belanga No. 1 Simp. Ayahanda, \\ Medan, Sumatera Utara, 20118, Indonesia \\ E-mail : Silviayang777@yahoo.com
}

\begin{abstract}
The research objective was to test and analyze the Effect of Current Ratio, Debt to Asset Ratio, Inventory Turnover, Company Size on Profitability in Property and Real Estate Companies listed on the Indonesia Stock Exchange (IDX) for the period 2012-2016 partially or simultaneously. The research used quantitative method. The population used in this study was the Property and Real Estate Companies listed on the Indonesia Stock Exchange with a total of 46 companies in the period 2012-2016. The sample in this study used data taking by means of purposive sampling. The number of samples used in this study were 31 companies with 155 observations. The results obtained were Current Ratio partially did not have a significant effect on Profitability. Partially Debt to Assets Ratio had no significant effect on profitability. Inventory Turnover in parallel l did not have significant effect on profitability. The size of the company partially had a positive and not significant effect on profitability. Current Ratio, Debt to Assets Ratio, Inventory Turnover and Company Size simultaneously did not have significant effect on Profitability in Property and Real Estate Companies listed on the Indonesia Stock Exchange for the period 2012-2016.
\end{abstract}

Keywords: Current ratio (CR), Debt to assets ratio (DAR), Inventory Turnover, Company Size, Profitability

\section{PENDAHULUAN}

Perusahaan property bergerak dibidang pembangunan, apartemen, kondominium, perumahan, real estate dan sebagainya. Perusahaan yang berada dalam sektor property dan real estate akan berkembang menjadi bisnis yang sangat menjanjikan dan menguntungkan di masa depan yang akan di pilih oleh investor sebagai alternatif berinvestasi, dimana disebutkan sebagai investasi jangka panjang. Berbisnis property semakin popular karena peminatnya terus bertambah setiap harinya dan dapat mendapatkan laba yang sangat besar. Tujuan didirikan perusahaan property untuk meningkatkan nilai suatu perusahaan sehingga dapat memberikan kesejahteraan bagi pemilik pemegang saham. Tujuan tersebut dicapai dengan selalu memaksimalkan labanya. Kemampuan perusahaan untuk memperoleh laba dalam hubungannya dengan penjualan, aktiva, maupun modal. Kinerja emiten sektor property sepanjang tahun 2016 pencapaiannya tidak lebih baik dari tahun 2015. Hal ini dikarenakan terjadi penurunan laba bersih pada mayoritas dari emiten property terbesar di Bursa Efek Indonesia (cnnindonesia.com).

Setiap hari aset lancar berlangsung sehingga diharapkan mendapatkan laba yang optimal. Perusahaan harus membuat kebijakan yang cermat terkait asset lancar agar tidak terjadi kelebihan investasi. Dikarenakan jika kelebihan investasi aka nada aset yang tidak terpakai dan akan memperbesar pula biaya yang dikeluarkan sehingga harus menurunkan 
laba untuk asset tersebut. Perusahaan dapat menggunakan dana yang bersumber dari internal maupun eksternal. Penggunaan dana yang bersumber eksternal yakni hutang harus memperhatikan risiko-risiko yang akan ditimbulkan dari pinjaman tersebut. Hutang yang semakin meningkat akan menimbulkan interest expense menjadi lebih tinggi sehingga akan mengurangi profit operasi dan mengakibatkan penurunan laba bersih, yang akan menyebabkan penurunan profitabilitas pada perusahaan.

Persediaan yang optimal dapat meningkatkan keuntungan yang diperoleh suatu perusahaan . Salah satunya dengan penjualan yang merupakan fungsi pemasaran untuk mendapatkan laba. Ukuran Perusahaan dinilai dari penetapan besar kecilnya perusahaan. Semakin tinggi total aset maka modal yang dimiliki perusahaan akan semakin besar, sehingga investor akan semakin aman. Semakin besar aset yang dimiliki perusahaan maka akan menghasilkan laba yang maksimal dan sebaliknya. Jika aset yang dimiliki kecil maka laba yang diperoleh akan semakin kecil pula.

\section{TINJAUAN PUSTAKA}

Current Ratio. Menurut Murhadi (2013:57), current ratio adalah "rasio yang biasa digunakan untuk mengukur kemampuan perusahaan memenuhi liabilitas jangka pendek (short run solvency) yang akan jatuh tempo dalam waktu satu tahun". Menurut Hery (2015:179), "Perusahaan yang memiliki lebih banyak kewajiban lancar dibandingkan asset lancar, maka biasanya perusahaan tersebut akan mengalami kesulitan likuiditas ketika kewajiban lancarnya jatuh tempo. Rasio lancar yang tinggi dapat saja terjadi karena kurang efektifnya manajemen kas dan persediaan". Menurut Hery (2016:52), Rumus yang digunakan untuk menghitung rasio lancar atau current ratio dapat digunakan sebagai berikut:

$$
\text { Current Ratio }=\frac{\text { Aset Lancar }}{\text { Kewajiban Lancar }}
$$

Menurut Horne dan Wachowicz (2012:254), "Profitabilitas berbanding terbalik dengan likuiditas, peningkatan likuiditas adalah merupakan lawan dari profitabilitas. Peningkatan likuiditas biasanya dibayar dengan penuruan profitabilitas".

Debt to Asset Ratio. Menurut Harahap (2013:304) debt to asset ratio ini menunjukkan "sejauh mana utang dapat ditutupi oleh aktiva, lebih besar rasionya lebih aman (solvable)". Menurut Sudana (2011:20), bahwa " Semakin Besar debt asset ratio menunjukkan semakin besar porsi penggunaan utang dalam membiayai investasi pada aktiva, yang berati pula resiko keuangan perusahaan meningkatkan dan sebaliknya". Menurut Hery (2015:196), rumus yang digunakan untuk menghitung debt to asset dapat digunakan sebagai berikut:

$$
\text { Debt to Asset Ratio }=\frac{\text { Total Utang }}{\text { Total Aset }}
$$

Menurut Brigham (2012:93), "perusahaan yang tidak memiliki utang (sehingga tidak memiliki beban bunga) akan melaporkan laba bersih yang lebih tinggi karena tidak ada bunga yang dikurangkan dari laba operasinya".

Perputaran Persediaan. Menurut Raharjaputra (2011:203), inventory turnover merupakan "salah satu rasio aktivitas yang mengukur kemampuan perusahaan dalam menjual produknya dalam suatu periode tertentu dibandingkan dengan jumlah persediaan yang dimiliki. Menurut Syamsuddin (2011:47) , Rasio perputaran persediaan mengukur efisiensi 
pengelolaan persediaan barang dagang. Untuk masing-masing jenis usaha biasanya ada suatu skala inventory yang dianggap baik sehingga kalau perputaran persediaan berada dibawah titik ini akan menandakan keadaan yang likuid atau inactive inventory sedangkan diatas titik ini akan menunjukkan jumlah inventory yang terlalu kecil, sehingga bisa menyebabkan kekurangan persediaan". Menurut Subramanyam \& Wild (2013:45), rumus yang digunakan untuk mencari rasio perputaran persediaan adalah sebagai berikut:

$$
\text { Inventory Turn Over }=\frac{\text { Harga Pokok Penjualan }}{\text { Rata-Rata Persediaan }}
$$

Menurut Jumingan (2016:228), "Rasio ini dihitung dengan memperbandingkan antara harga pokok penjualan dengan rata-rata persediaan. Rasio ini mununjukkan berapa kali dana yang ditanam dalam persediaan ini berputar dalam satu tahun / periode. Semakin besar turn over berati semakin baik".

Ukuran Perusahaan. Menurut Sitanggang (2013:76) "Ukuran perusahaan dengan kapitalisasi pasar atau penjualan yang besar menunjukkan prestasi perusahaan. Perusahaan yang besar akan lebih mudah mendapatkan akses ke sumber dana untuk memperoleh tambahan modal dengan utang". Menurut Rusdianto (2013:44), ukuran perusahaan ini merupakan variabel penduga yang banyak digunakan untuk menjelaskan variasi pengungkapan dalam laporan tahunan perusahaan. Oleh karena itu perusahaan besar akan mengungkapkan informasi yang lebih banyak sebagai upaya untuk mengurangi biaya keagenan tsb. Sebaliknya perusahaan kecil umumnya berada pada situasi persaingan yang ketat dengan perusahaan yang lain. Firm Size dihitung dengan Logaritma natural (Ln) dari total aset. Skala pengukuran yang digunakan adalah:

$$
\text { Firm Size }=\operatorname{Ln}(\text { Total aset })
$$

Menurut Brigham (2010:136), "Jika perusahaan memiliki terlalu banyak aset, maka biasanya modalnya terlalu tinggi dan labanya akan tertekan. Di lain pihak, jika aset terlalu rendah penjualan yang menguntungkan akan hilang".

Profitabilitas. Menurut Harahap (2016:304), profitabilitas menggambarkan kemampuan perusahaan mendapatkan laba melalui semua kemampuan, dan sumber yang ada seperti kegiatan penjualan, kas, modal, jumlah karyawan, jumlah cabang, dan sebagainya. Menurut Sunyoto (2013:113), Daya tarik pemilik perusahaan,yaitu pemegang saham dalam suatu perseroan adalah proftabilitas. Pemilik juga tertarik pada pembagian laba yang menjadi haknya yaitu seberapa banyak yang diinvestasikan kembali dan seberapa banyak yang dibayarkan sebagai deviden kepada mereka. Akhirnya pemilik juga berkepentingan jika saham dijual kepada umum. Menurut Hery (2015:228), Rumus yang di gunakan untuk menghitung hasil pengembalian atas aset adalah :

$$
\text { Hasil Pengembalian atas Aset }=\frac{\text { Laba Bersih }}{\text { Total Aset }}
$$

Berdasarkan uraian tersebut maka secara konseptual, dapat disusun kerangka.

\section{METODE PENELITIAN}

Metode penelitian yang digunakan dalam penelitian ini adalah metode kuantitatif. Pengumpulan data dengan menggunakan instrument penelitian dan untuk menguji hipotesa 
analisa data yang bersifat kuantitatif. Jenis penelitian ini menggunakan penelitian yang bersifat deskriptif. Dimana penelitian deskriptif berkaitan tentang suatu rumusan masalah terhadap pertanyaan variabel mandiri baik satu variabel maupun lebih. Sedangkan data penelitian ini menggunakan data sekunder.

Penelitian ini bersifat hubungan kausal yaitu sebab akibat. Variabel yang mempengaruhi yakni variabel independen, sedangkan variabel yang dipengaruhi yakni variabel dependen. Perusahaan yang di teliti merupakan perusahaan yang bergerak di bidang property dan real estate yang tercatat di BEI dari tahun 2012 sampai tahun 2016 yang mempunyai 46 perusahaan .Teknik yang dipilih dalam pengambilan sampel menggunakan teknik purposive sampling. Kriteria yang dapat dijadikan dalam pemilihan sampel yaitu:

1. Perusahaan properti dan real estate yang listing di BEI tahun $2012-2016$.

2. Perusahaan properti dan real estate yang mempublikasikan laporan keuangan berturutturut di BEI tahun 2012 - 2016.

3. Perusahaan properti dan real estate yang mempunyai laba atau profit yang positif selama tahun $2012-2016$

Dari 46 perusahaan property dan real estate yang terdaftar di BEI tahun 2012 sampai tahun 2016 yang dapat memenuhi kriteria tersebut menjadi 31 perusahaan, kemudian dikalikan 5 tahun pengamatan. Dalam penelitian ini digunakan model regresi linear berganda.

\section{HASIL DAN PEMBAHASAN}

Secara umum, tujuan penelitian untuk menganalisa dan mengetahui signifikansi pengaruh current ratio, debt to asset ratio, perputaran persediaan dan ukuran perusahaan terhafap profitabilitas pada perusahaan properti dan real estate yang terdaftar di BEI tahun 2012 sampai dengan tahun 2016. Hasil analisis berdasarkan data sekunder dari 155 observasi untuk mengestimasi persamaan regresi linear berganda yakni :

Tabel 1. Persamaan Regresi

\begin{tabular}{|c|c|c|c|c|c|c|c|}
\hline & \multirow[b]{2}{*}{ Model } & \multicolumn{2}{|c|}{ Unstandardized Coefficients } & \multirow{2}{*}{\multicolumn{2}{|c|}{$\begin{array}{c}\text { Standardized Coefficients } \\
\text { Beta }\end{array}$}} & \multirow[b]{2}{*}{$\mathbf{t}$} & \multirow[b]{2}{*}{ Sig. } \\
\hline & & $\mathbf{B}$ & Std. Error & & & & \\
\hline \multirow[t]{5}{*}{1} & (Constant) & -0.540 & 0.367 & & & -1.47 & 00.144 \\
\hline & SQRT_CR & -0.029 & 0.021 & & -0.129 & -1.39 & 00.166 \\
\hline & SQRT_DAR & -0.107 & 0.074 & & -0.135 & -1.43 & 90.152 \\
\hline & SQRT_ITO & 0.004 & 0.003 & & 0.106 & 1.24 & 70.214 \\
\hline & SQRT_UK & 0.166 & 0.071 & & 0.196 & 2.33 & 20.021 \\
\hline
\end{tabular}

a. Dependent Variable: SQRT_PROFIT

Sumber : Hasil pengolahan data, 2018

$$
S Q R T \_P R O F I T=-0,540-0,029 S Q R T \_C R-0,107 S Q R T \_D A R+0,004 S Q R T \_I T O+0,166 S Q R T \_U K
$$

Interprestasi persamaan tersebut adalah :

1. Constanta sebesar $-0,540$, jika current ratio debt to asset ratio, perputaran persediaan dan ukuran perusahaan bernilai nol (0) maka profitabilitas sebesar 0,540.

2. Koefisien regresi Current ratio sebesar -0,029 menyatakan bahwa setiap kenaikan current ratio sebesar 1satuan maka terjadi penurunan terhadap profitabilitas sebesar 0,029.

3. Koefisien regresi debt to asset ratio sebesar $-0,107$ menyatakan bahwa setiap kenaikan debt to asset ratio sebesar 1 satuan maka terjadi penurunan terhadap profitabilitas sebesar 0,107 . 
4. Koefisien regresi perputaran persediaan sebesar 0,004 menyatakan bahwa setiap kenaikan perputaran persediaan sebesar 1 satuan maka terjadi kenaikan terhadap profitabilitas sebesar 0,004.

5. Koefisien regresi ukuran perusahaan sebesar 0166 menyatakan bahwa setiap kenaikan ukuran perusahaan 1 satuan maka terjadi kenaikan terhadap profitabilias sebesar 0,166

Koefisien determinasi mengukur seberapa jauh kemampuan untuk menerangkan variabel variabel dependen.

Tabel 2. Uji Koefisien Determinasi

\begin{tabular}{cccccrc}
\hline Model & R & R Square & $\begin{array}{c}\text { Adjusted R } \\
\text { Square }\end{array}$ & $\begin{array}{c}\text { Std. Error of the } \\
\text { Estimate }\end{array}$ & Durbin-Watson \\
\hline 1 & $.246^{\mathrm{a}}$ & .061 & & .036 & .09847 & 1.955
\end{tabular}

a. Predictors: (Constant), SQRT_UK, SQRT_ITO, SQRT_CR, SQRT_DAR

b. Dependent Variable: SQRT_PROFIT

Sumber : Hasil Pengolahan data,2018

Tabel 2 menunjukkan bahwa besarnya nilai Adjusted $\mathrm{R}^{2}$ adalah 0,036. Dapat dikatakan bahwa 3.6\% variabel profitabilitas dapat dijelaskan oleh variabel current ratio, debt to asset ratio, perputaran persediaan dan ukuran perusahaan sedangkan sisanya sebesar $(100 \%-3,6 \%=96,4 \%)$ merupakan variasi variabel lain yaitu : perputaran piutang, perputaran kas, biaya operasional, dll yang tidak dijelaskan dalam penelitian ini.

Tabel 3. Hasil Analisis Koefisien Korelasi

\begin{tabular}{|c|c|c|c|c|c|c|}
\hline \multicolumn{2}{|r|}{ Model } & \multirow{2}{*}{$\begin{array}{r}\text { Sum of Squares } \\
0.094\end{array}$} & \multirow[t]{2}{*}{ df } & Mean Square & \multirow{2}{*}{$\frac{\mathbf{F}}{2.418}$} & \multirow{2}{*}{$\frac{\text { Sig. }}{0.051}$} \\
\hline 1 & Regression & & & 0.023 & & \\
\hline & Residual & 1.454 & 150 & 0.010 & & \\
\hline & Total & 1.548 & 154 & & & \\
\hline \multicolumn{7}{|c|}{ a. Predictors: (Constant), SQRT_UK, SQRT_ITO, SQRT_CR, SQRT_DAR } \\
\hline
\end{tabular}

Sumber : Hasil Pengolahan data,2018

Tabel 3 menunjukkan bahwa, setelah dilakukan pengujian secara simultan dari variabel variabel Current Ratio $(C R)$, Debt to Asset Ratio (DAR), Perputaran Persediaan dan Ukuran Perusahaan mendapatkan nilai signifikan 0,051. Hal ini berati bahwa variabel Current Ratio (CR), Debt to Asset Ratio (DAR), Perputaran Persediaan dan Ukuran Perusahaan tidak berpengaruh secara simultan terhadap Profitabilitas.

\section{KESIMPULAN DAN SARAN}

Hasil penelitian ini menyimpulkan bahwa Ukuran Perusahaan secara parsial berpengaruh positif tetapi tidak signifikan terhadap Profitabilitas, sedangkan Current Ratio $(C R)$, Debt to Asset Ratio (DAR), Perputaran Persediaan secara parsial tidak berpengaruh terhadap Profitabilitas. 


\section{DAFTAR PUSTAKA}

Brigham, Houston.2012. Dasar-Dasar Manajemen Keuangan. Salemba Empat Harahap, Sofyan Syafri. 2016. Analisis Kritis atas laporan keuangan. Cetakan Ketiga belas. Jakarta: PT.RajaGrafindo Persada.

Hery. 2015. Analisis Laporan Keuangan Pendekatan Rasio Keuangan. Cetakan Pertama. Yogyakarta : CAPS (Center for Academic Publishing Service).

Hery. 2016. Financial Ratio For Business. Jakarta: PT. Grasindo.

Jumingan. 2016. Analisis Laporan Keuangan. Cetakan keenam. Jakarta: PT Bumi Aksara.

Murhadi, Dr. Werner R.. 2013. Analisis Laporan Keuangan Proyeksi dan Valuasi Saham. Jakarta: SalembaEmpat.

Raharjaputra, Hendra S. 2011.Manajemen Keuangan dan Akuntansi untuk Eksekutif Perusahaan. Cetakan Pertama. Jakarta: Salemba Empat.

Sitanggang, J.P. 2013. Manajemen Keuangan Perusahaan. Ed 2. Jakarta: Mitra Wacana Media.

Subramanyamdan John Wild. 2010. AnalisisLaporanKeuangan. Ed. 10, Jakarta: SalembaEmpat.

Sudana, I Made. 2011. Manajemen Keuangan Perusahaan : Teori \& Praktik. Jakarta: Penerbit Erlangga.

Sunyoto, Danang. 2013. Metodologi Penelitian Akuntansi. Cetakan Pertama. Bandung: PT Refika Aditama.

Syamsuddin, Lukman. 2011. Manajemen Keuangan Perusahaan. Cetakan Kesebelas. Jakarta: PT RajaGrafindo Persada.

Rusdianto, Ujang. 2013. CSR Communication A Farmwork for PR Practitioners. Cetakan pertama. Yogyakarta: Graha Ilmu. 